\title{
Article \\ Structural Behavior of Composite Floor System Using Cold-Formed Thin-Walled C Steel Channel Embedded Foam Concrete
}

\author{
Dianzhong Liu ${ }^{1}$, Feng Fu ${ }^{2, *(1)}$ and Wanjuan Liu ${ }^{1}$ \\ 1 School of Civil Engineering, Jilin Jianzhu University, Changchun 130118, China; \\ liudianzhong@jlju.edu.cn (D.L.); liuwanjuan@jlju.edu.cn (W.L.) \\ 2 Department of Civil Engineering, School of Mathematics, Computer Science \& Engineering, City, \\ University of London, Northampton Square, London C1V 0HB, UK \\ * Correspondence: feng.fu.1@city.ac.uk
}

check for updates

Citation: Liu, D.; Fu, F.; Liu, W. Structural Behavior of Composite Floor System Using Cold-Formed Thin-Walled C Steel Channel Embedded Foam Concrete. Appl. Sci. 2021, 11, 9888. https://doi.org/ 10.3390/app11219888

\section{Academic Editors: Khan}

Mohammad Iqbal and Dario De Domenico

Received: 25 July 2021

Accepted: 15 October 2021

Published: 22 October 2021

Publisher's Note: MDPI stays neutral with regard to jurisdictional claims in published maps and institutional affiliations.

Copyright: (c) 2021 by the authors. Licensee MDPI, Basel, Switzerland. This article is an open access article distributed under the terms and conditions of the Creative Commons Attribution (CC BY) license (https:// creativecommons.org/licenses/by/ $4.0 /)$.

\begin{abstract}
In this paper, a new composite floor system using cold-formed thin-walled C steel channel embedment and a foam concrete slab is developed. This new type of floor system features lightweight, high fire-resistant, and high anti-corrosion features, and can be used for multi-story buildings, providing a promising new alternative floor system for the construction market. Two four-point bending tests were carried out to investigate the flexural capacity and failure modes of this new type of composite slab. Based on the test results, a nonlinear finite element model was developed using general software package ABAQUS. The model is validated using the test results. Using this model, parametric studies were performed to study the key parameters affecting the structural behavior of this new type of composite floor system. Different parameters such as density of the foam concrete, grade of the cold-formed thin-walled C steel channel embedment, and spacing of the cold-formed thin-walled $C$ steel channel were investigated. Their contributions to the overall moment capacity and their effect on the failure modes of this type of composite slab were discovered. Based on experimental results and FE results, design formulas for ultimate flexural capacity of this new type of composite slabs were also developed which can accurately predict their flexural capacity.
\end{abstract}

Keywords: flexural capacity; composite floor slab; foam concrete; ABAQUS

\section{Introduction}

Foam concrete is a cellular lightweight concrete with reduced density. It is made of cement and fly ash with a compressive strength between 9 and $24 \mathrm{MPa}$ in different densities [1]. The density of foam concrete varies from $400 \mathrm{~kg} / \mathrm{m}^{3}$ to $1600 \mathrm{~kg} / \mathrm{m}^{3}$, much lighter than normal concrete. Up to now, foamed concrete has been widely used for nonstructural members in buildings, working as a lightweight material for sound barriers, and as filling for composite members [2]. It has also been used as filling for masonry due to its good thermal insulation and ability to protect against fires [3]. Although foam concrete has been widely used for non-structural purposes, there is an increasing trend for its use in structural members. Little research has been done for the compressive and flexural resistance of foam concrete members [4]. Yanet al. made numerical studies on steel-UHPC-steel sandwich beams with novel enhanced C-channels [5]. Sohel et al. [6] studied the behavior of steel-concrete-steel sandwich structures with lightweight cement composite and novel shear connectors. However, no studies on composite structures using foam concrete can be found in the current literature. Due to its inherent low strength, foam concrete has to be further reinforced by steel reinforcements for structural purpose [7-9]. Jones et al. [10] studied the heat of hydration in foamed concrete. Kearsleya et al. [11] studied the effect of high fly ash content on the compressive strength of foamed concrete. Hashimoto et al. [12] introduced the process of continuous manufacturing of lightweight foamed concrete. 
The cold-formed thin-walled steel structure has been developed for more than half a century, and has been widely used in many construction projects. In 2001, the United States, Canada, and Mexico integrated the specifications for cold-formed thin-walled steel, and released the integrated specification "Code for Design of Cold-Formed Steel Components" [13]. China also published the national standard "Technical Specification for Cold-Formed Thin-Walled Steel Structures" (GB50018-2002) in 2002 [14].In 1987, in order to promote the application of profiled steel-concrete composite slabs in the UK, Wright and Evans [15] did a large number of related tests, which greatly promoted the application of composite slabs. In 1997, Sauerborn Ingeborg and Bode Helmut [16] analyzed the slip of composite slabs. In 2004, Elghazoul and Izzuddin [17] used high-strength concrete instead of ordinary concrete to cast composite slabs, and analyzed the stiffness changes of composite slabs and the performance of the slabs when the ultimate load was reached. Crisinel and Marimon [18] developed a method to calculate the bearing capacity of composite slabs, and verified the feasibility of this calculation method through experiments. In 2008, Youn-Ju Jeong [19] proposed a new method that can calculate the composite board by launching a test, which is more economical and simpler than the traditional test method.

Therefore, to enable a further application of this new type of concrete to the current construction projects such as tall buildings [20-22], a new composite floor slab system made of cold-formed thin-walled $C$ steel channel embedment and foam concrete is developed in this paper. As it shown in Figure 1, it is a one-way slab system. It uses a cold-formed thin-walled $C$ steel channel as a major steel skeleton embedded into the foam concrete, which is laterally connected by steel belts. After casting the foam concrete, the one-way slab is formed. Due to the lightweight feature and excellent fire resistance of foam concrete compared to normal concrete, this new composite slab system exhibits a great application prospect in multi-story buildings. However, the failure mechanism and the flexural capacity of this type of new composite floor slab system are still not clear. Therefore, in this paper, a full-scale bending test on composite floor slabs using cold-formed thin-walled C steel channel embedment is conducted, and the failure mechanism and the flexural capacity of this type of new slab system are investigated. In the meantime, a FE model is built using ABAQUS, which is validated by the test results. It is used to investigate the effect of different design parameters on the behavior of this type of floor system. Based on the experimental and numerical investigations, the formula to calculate the flexural capacity of this type of composite slabs is also developed.

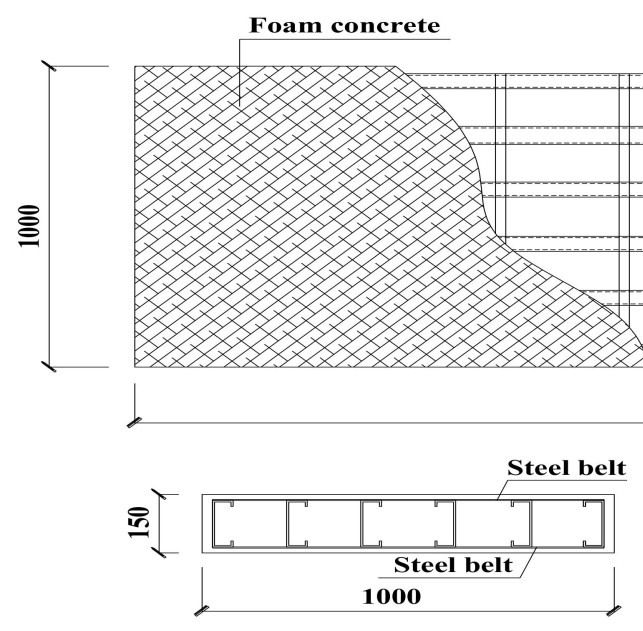

(a)

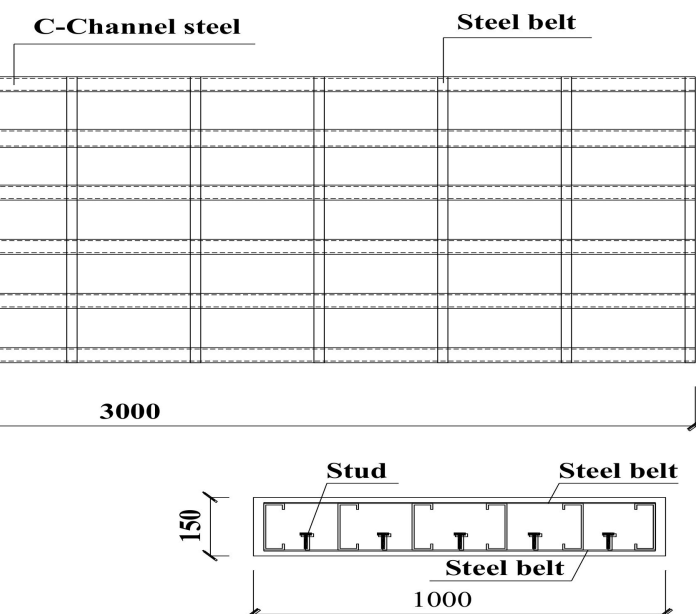

(b)

Figure 1. Foam concrete composite floor slabs with cold-formed thin-walled C steel channels embedment (mm). (a) Specimen B-1; (b) Specimen B-2. 


\section{Four-Point Bending Test}

The four-point bending test was performed in the structural lab of Jilin Jianzhu University. The detailed testing setup and test procedures are introduced here. The instrumentation and test procedure follows [23-29].

\subsection{Test Specimens}

As shown in Figure 1, two specimens were fabricated: B-1and B-2. The difference between these two specimens is that studs with a diameter of $13 \mathrm{~mm}$ and a height of $60 \mathrm{~mm}$ were welded in B-2 (see Figure 1b).The cold-formed thin-walled C steel channels are placed in a longitudinal direction, is laterally connected by steel belts with a spacing of $200 \mathrm{~mm}$ to form a steel skeleton. After casting the foam concrete, the one-way slab is formed. The dimension of the slab is $3000 \times 1000 \times 150 \mathrm{~mm}$. Chinese 235B [30] with a yield strength of $235 \mathrm{MPa}$ is used for the cold-formed thin-walled $\mathrm{C}$ steel channels and the steel belts. The ultimate strength of Chinese235B is $370 \sim 500 \mathrm{MPa}$. The density of the foam concrete is $1200 \mathrm{~kg} / \mathrm{m}^{3}$ [9], with a compressive strength of $17.8 \mathrm{MPa}$. The mix design is shown in Table 1 . The section size for cold-formed thin-walled $\mathrm{C}$ steel channel is $\mathrm{C} 100 \times 50 \times 20 \times 2.0 \mathrm{~mm}$, with spacing of $180 \mathrm{~mm}$. The steel belt is $50 \times 2.0 \mathrm{~mm}$ with a spacing of $200 \mathrm{~mm}$. The concrete cover is $25 \mathrm{~mm}$.

Table 1. Mix ratio of foam concrete of $1200 \mathrm{~kg} / \mathrm{m}^{3}$ density.

\begin{tabular}{cccccc}
\hline $\begin{array}{c}\text { Density } \\
\left(\mathbf{k g} / \mathbf{m}^{\mathbf{3}}\right)\end{array}$ & $\begin{array}{c}\text { Weight of Fly Ash } \\
(\mathbf{k g})\end{array}$ & $\begin{array}{c}\text { Weight of Cement } \\
\mathbf{( \mathbf { k g } )}\end{array}$ & $\begin{array}{c}\text { Weight of Water } \\
\mathbf{( \mathbf { k g } )}\end{array}$ & $\begin{array}{c}\text { Weight of Foam Agent } \\
(\mathbf{k g})\end{array}$ & $\begin{array}{c}\text { Volume of Foam } \\
\left(\mathbf{m}^{\mathbf{3}}\right)\end{array}$ \\
\hline 1200 & 200 & 800 & 400 & 0.32 & 0.2916 \\
\hline
\end{tabular}

\subsection{Test Set-Up}

As it is shown in Figure 2, the four-point bending test was performed. The supports were placed $100 \mathrm{~mm}$ away from the end of the slab. Fixed hinge support was used at one end and roller support was used at the other end. The MTS test system with electrohydraulic servo (range $500 \mathrm{kN}$ ) was used for vertical loading. The MTS loading system transferred force through loading beams to the slabs. The load cell in the MTS test system could directly transmit pressure sensing data to the computer system, and could control the loading rate, switch loading mode, and change loading force and displacement by computer. The spacing of the two loading beams was $1000 \mathrm{~mm}$.

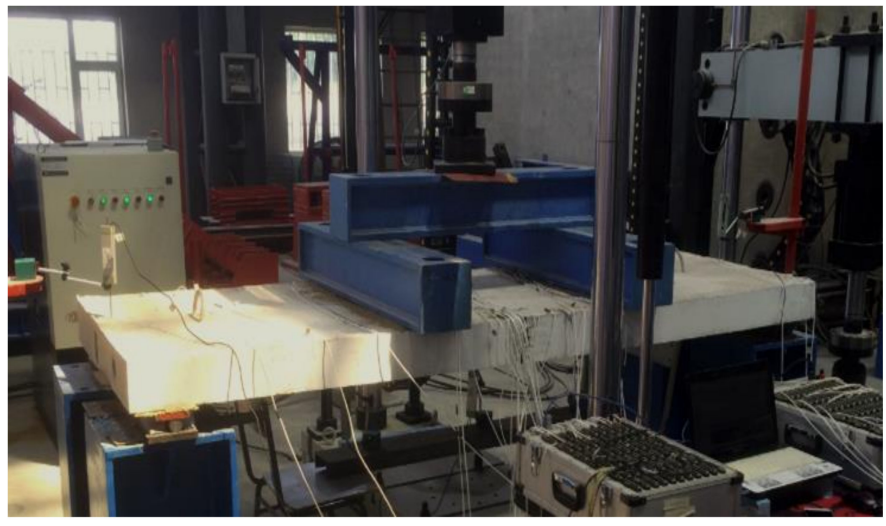

(a)

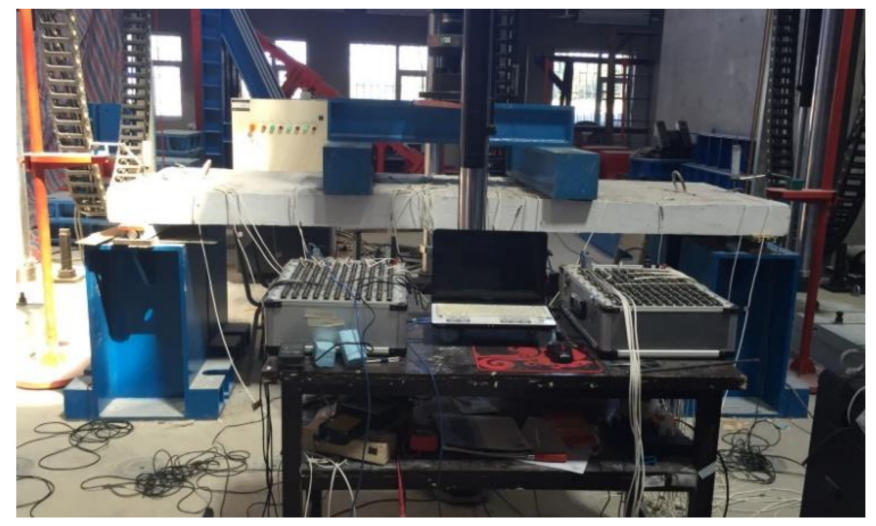

(b)

Figure 2. Test arrangements. (a) TestB-1; (b) testB-2. 


\subsection{Instrumentation}

During the tests, the conventional instrumentation for flexural tests was used, which was comprised of LVDTs and strain gauges. The strain gauges were mounted on the cold-formed thin-walled $\mathrm{C}$ steel channels at various locations to monitor the change of the strain in the cold-formed thin-walled C steel channels, as is shown in Figure 3.

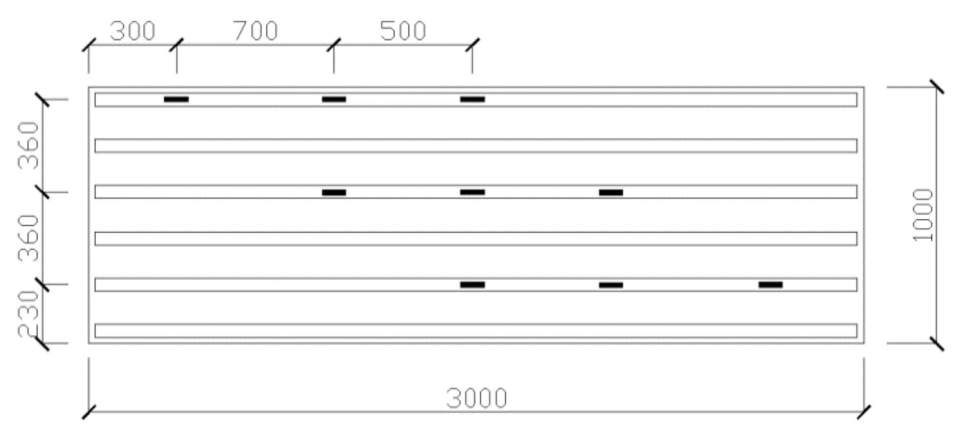

(a)

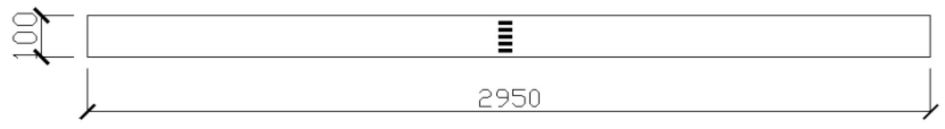

(b)

Figure 3. Schematic diagram of measuring points on cold-formed thin-walled $C$ steel channels. (a) Location of the strain gauges at the top and bottom flanges of the cold-formed thin-walled C steel channels; (b) location of the strain gauges at the webs of the cold-formed thin-walled C steel channels.

In addition to measuring of the strains in the cold-formed thin-walled $C$ steel channels, there were 10 strain gauges on the upper surface of foam concrete, 4 of which were in mid span, 4 at three points on both sides, 2 at the two ends near the support, and 5 strain gauges were placed along the section height according to the position of the lower surface and the strain gauges on the upper surface. The strain gauges used for measuring foam concrete are shown in Figure 4.

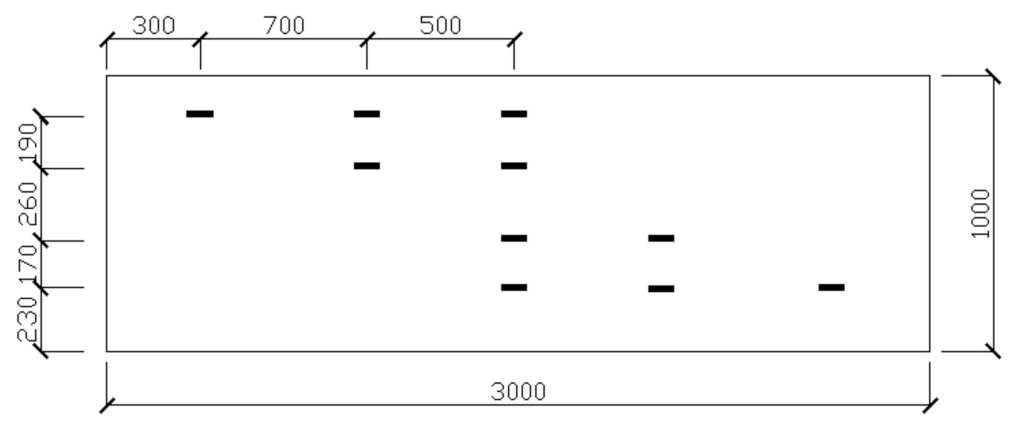

(a)

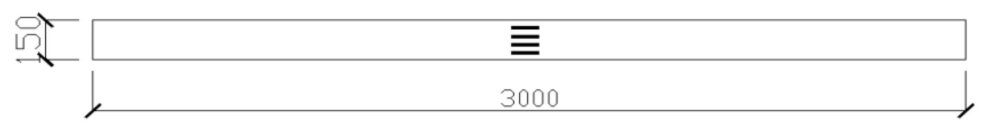

(b)

Figure 4. Schematic diagram of measuring points of foam concrete slab strain gauge. (a) Strain gauges at top and bottom surface of the foam concrete slab; (b) Strain gauges at the long edge of the foam concrete slab. 
The LVDTs were installed at mid-span, at two loading points and two supports, respectively. Their locations are shown in Figure 5. TheYHD-100 dial gauges were also placed at the midspan and the two supports as shown in Figure 5. DJCK-2crack measurement device is used to record the crack patterns and crack width of the slab.

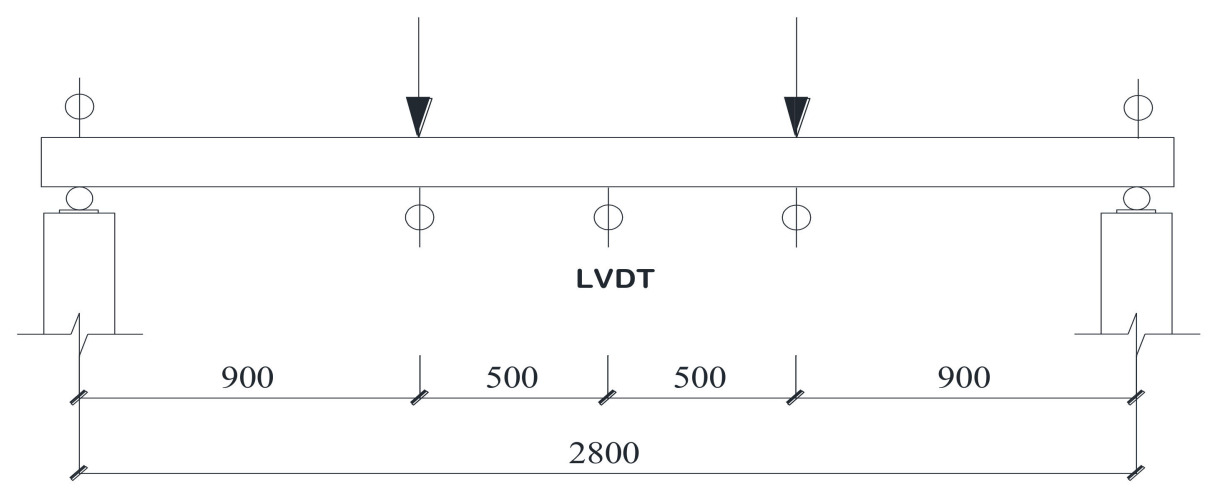

Figure 5. Schematic diagrams of LVDTs.

\subsection{Loading Procedure}

The combined load and displacement control method was used during the loading process using the MTS test system. Before the start of the test, the specimens were preloaded to a smaller load to check whether all the instrumentations were working correctly. During the test, the load was applied through several increments; the loading also stopped after each increment for taking the readings, such as the dial gauge readings. The load increased until the failure of the slabs.

The test adopted a load-displacement comprehensive control method. Before the test started, two pre-loading steps were carried out, and the load was $2 \mathrm{kN}$ each time. At the beginning of the test, the loading level was controlled by the load increment, and the loading rate was $2 \mathrm{kN} / \mathrm{min}$. After cracks appeared, the loading rate was adjusted to $1 \mathrm{kN} / \mathrm{min}$ until the specimen showed large inelastic deformation. At each increment, the load was kept constant for $10 \mathrm{~min}$. At the same time, the readings of the instrumentations were recorded. When obvious plastic deformation was observed in the specimen, the loading method was changed to displacement control of the displacement in the middle of the span. The increment was $5 \mathrm{~mm}$ when the concrete in the compression zone of the pure bend section was crushed, in which case the loading could be stopped.

The YHD-100 resistance dial gauges were placed in the middle span and below the two loading points. In order to monitor the influence of the settlement of the support on the deflection, the other two YHD-50 resistance dial gauges were installed at the support. The dial gauges were connected to the $\mathrm{DH} 3818$ data logger, and then connected to the computer.

\subsection{Test Results and Discussion}

The tests can be divided into three stages: elasticity, elastoplasticity, and failure. At the initial stage of loading, the stress and strain of cold-formed thin-walled C steel channels and foam concrete were small. As the load increased, cracks were noticed when the load was about $15 \%$ of the ultimate load. When the load further increased, the composite slabs entered the elastic-plastic stage, the number of flexural cracks in the pure bending zone increased, the crack width became wider, and some were propagated through the cold-formed thin-walled C steel channels. As is also noticed in [31,32], the variability of the crack width along the element height was directly related to tensile and compressive stresses arising at the critical section. At this time, the tensile force at the tension zone of the composite slabs was fully resisted by the lower flange of cold-formed thin-walled C steel channels. Apart from the cracks appearing in the pure bending section, when the load was $50 \%$ of the ultimate load, a vertical crack in the shear span zone was also noticed. The readings from the strain gauges indicated that the upper flanges of the cold-formed 
thin-walled C steel channels were under compression and the lower flanges were in tension, and the lower flange of cold-formed thin-walled $C$ steel channels began to yield under tension, while the upper flanges were still in the elastic stage. After the yield of lower flange, the crack width of the composite slab increased correspondingly. The neutral axis of the cross section of the composite slab rose slightly. As the load continued to increase, the upper flange of cold-formed thin-walled C steel channels started to yield, and the strain of the foam concrete increased gradually, and finally the foam concrete was crushed and destroyed. The crack distributions of some stages of the tests are shown in Figure 6.

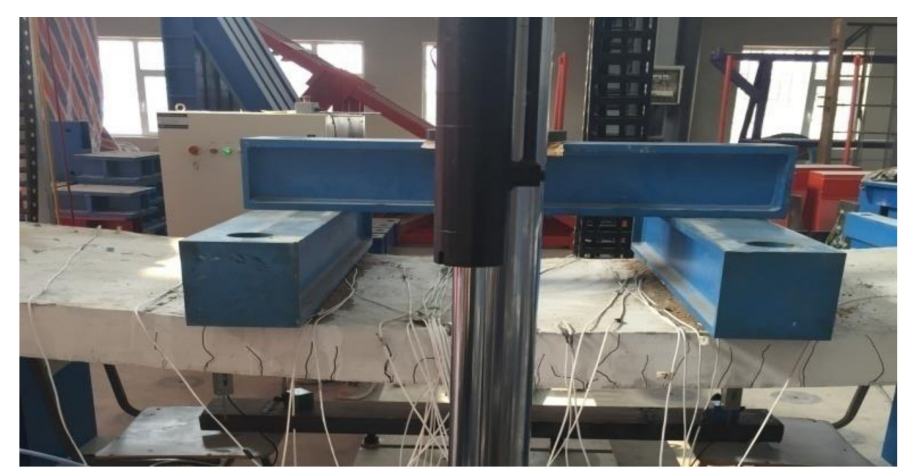

(a)

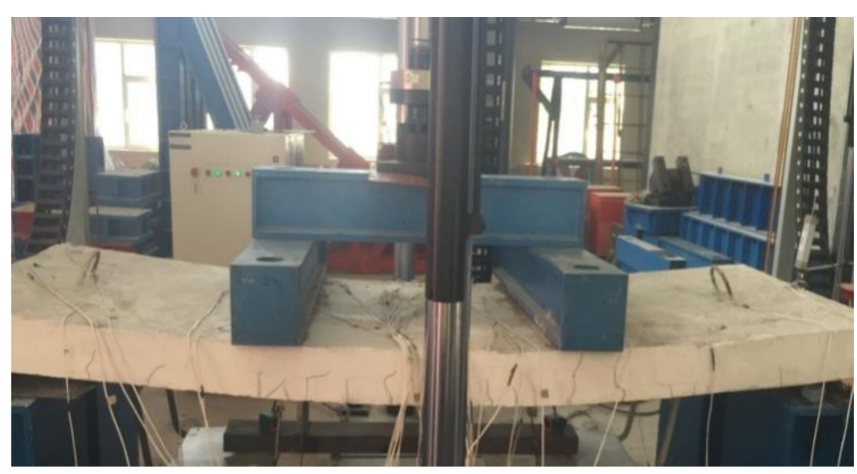

(b)

Figure 6. The crack distributions of some stages of the tests. (a) Vertical cracks of B-1; (b) Vertical cracks of B-2.

\subsubsection{Load-Deflection Relationship}

Figure 7 shows the comparation of the deflection of tests B-1 and B-2. It can be seen that the results are very similar. It also shows that the studs are not necessary for this type of composite floor system.

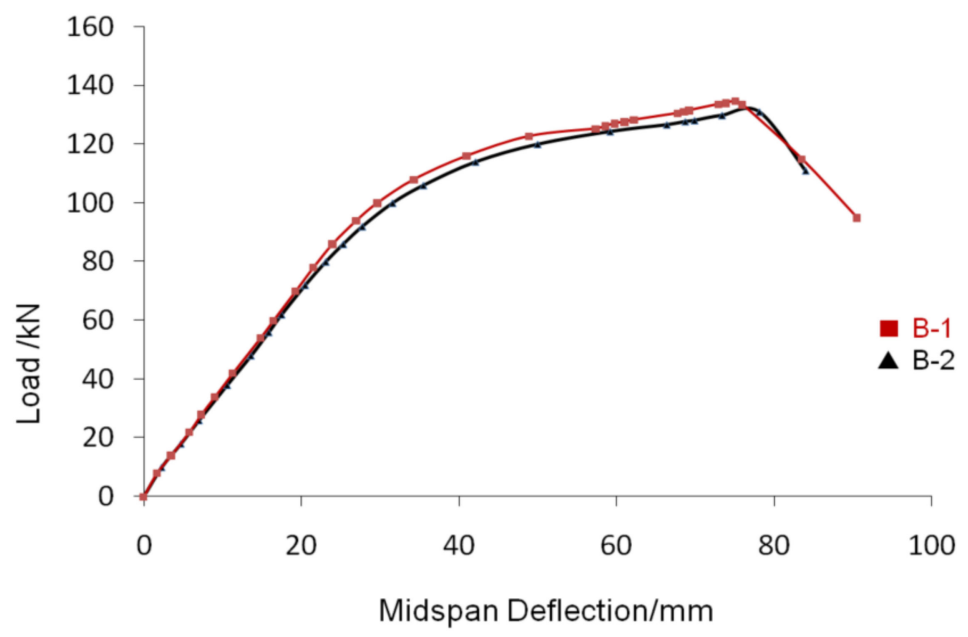

Figure 7. Load-deflection relationship of tests B-1 and B-2.

It can be seen that, at the initial stage, the slab deforms as a normal concrete slab. This is because of the compatibility of the cold-formed thin-walled C steel channels and foam concrete at the elastic stage of the slab. With the increase of the load, cracks were observed at the bottom of the slab. Due to the contribution of the cold-formed thin-walled C steel channels, the deflection increases quickly, but the load does not increase too much, as the slab is in elastic-plastic stage. As the cold-formed thin-walled C steel channels have not started to yield, the deformation is primarily due to the bond slip between the concrete and the cold-formed thin-walled C steel channels. However, with the development of the crack, 
the slab goes to the plastic stage, and the slip between the concrete and the cold-formed thin-walled $C$ steel channels causes the flexural rigidity of the slabs to reduce sharply until the failure is noticed.

\subsubsection{Load-Strain Relationship}

Figure $8 \mathrm{a}$ is the readings of strain gages along the thickness of the slab at both edges of specimen B-1midspan, and the location of the gauges is shown in Figure $4 \mathrm{~b}$. Figure $8 \mathrm{~b}$ is the reading of the strain gauges along the height of the web of the cold-formed thin-walled C steel channels at specimen B-1midspan, and the location of the strain gauges is shown in Figure 3b. From Figure 8, it can be seen that, when the load is small, (load is $0.09 \mathrm{Pu}$ ), the strain distribution for both foam and cold-formed thin-walled $C$ steel channels are linearly distributed along the section height of the slab. However, with the increase of the load, the distribution becomes non-linear. This is due to the slip between the cold-formed thin-walled $C$ steel channels and the foam concrete. It can also be seen that the strain in cold-formed thin-walled C steel channels is primarily in tension.

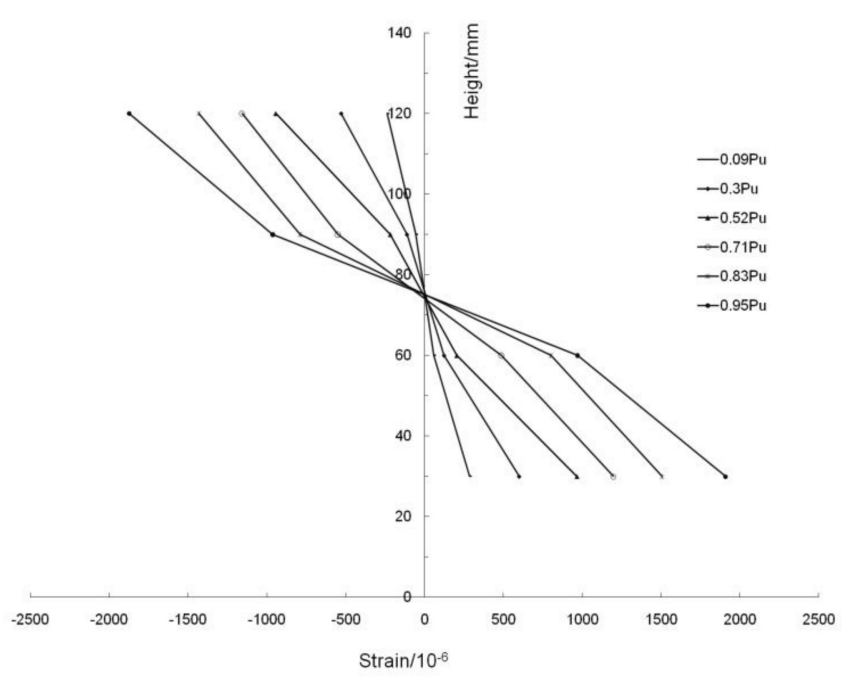

(a)

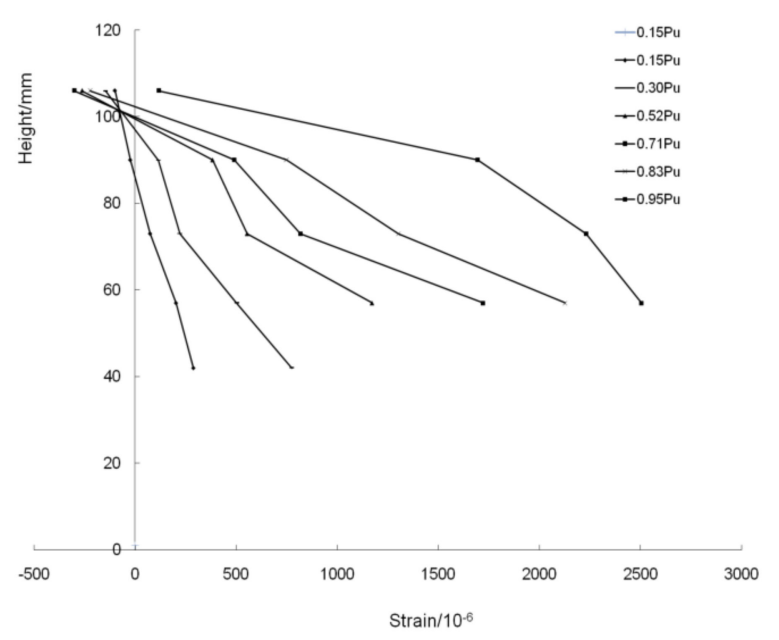

(b)

Figure 8. Strain distributions along the height of the slab at different loading stages. (a) Foam concrete slab; (b) Cold-formed thin-walled C steel channel.

Figure 9a is the reading of the strain gauges horizontally along the direction of the plate span at the top surface of the slab of specimen B-1midspan, and the location of the gauges is shown in Figure $4 \mathrm{a}$. Figure $9 \mathrm{~b}$ is the reading of the strain gauges horizontally along the direction of the plate span at the top flange of the cold-formed thin-walled $\mathrm{C}$ steel channels at specimen B-1midspan, and the location of the gauges is shown in Figure 3a. It can be seen from Figure 9 that when the load is less than $70 \%$ of the ultimate load, the compressive strain of the foamed concrete increases slowly; when the load is greater than $70 \%$ of the ultimate load, the compressive strain of the foamed concrete increases at a faster rate until the specimen fails. When the load is less than $90 \%$ of the ultimate load, the compressive strain of the cold-formed thin-walled $C$ steel channels basically changes linearly; when the load reaches $90 \%$ of the ultimate load, the compressive strain of the cold-formed thin-walled $\mathrm{C}$ steel channels basically reaches the yield and enters the plastic stage until it fails. 


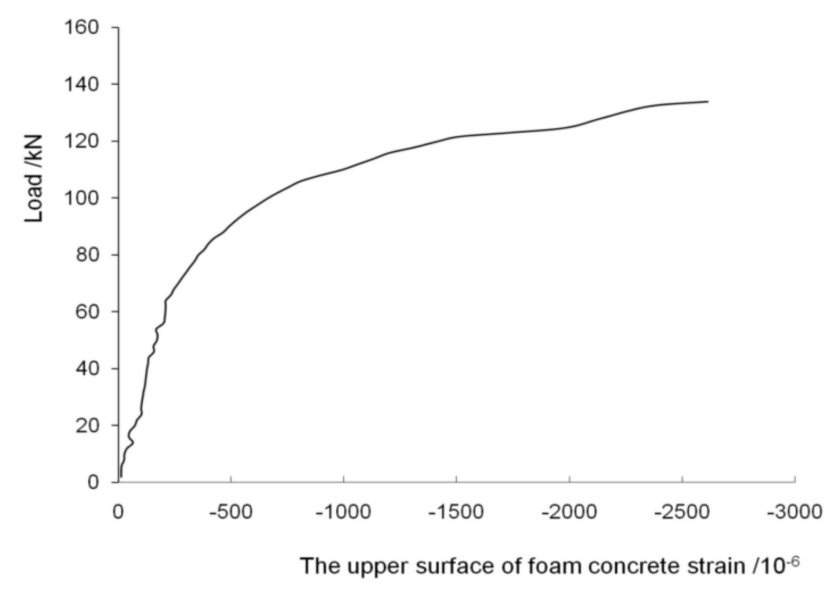

(a)

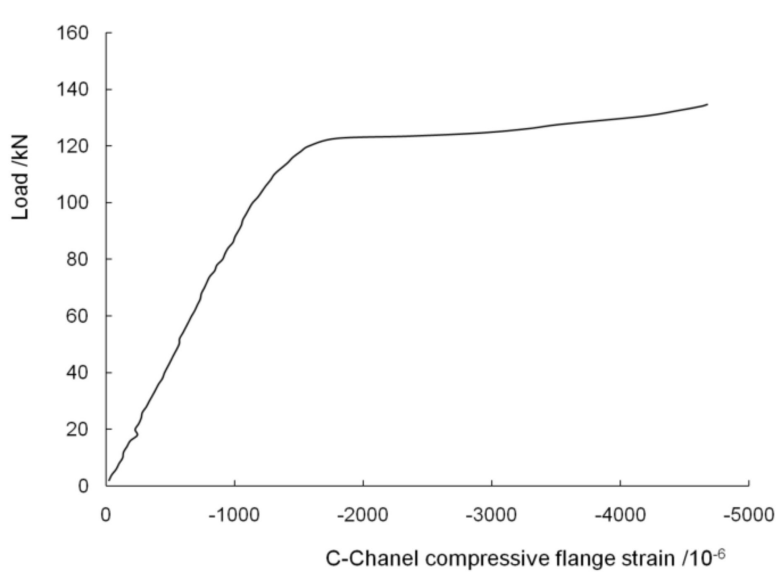

(b)

Figure 9. Load-strain relationships of the top surface of the foam concrete and bottom surface of the cold-formed thin-walled C steel channels. (a) Top surface of the foam concrete slab; (b) Top surface of the cold-formed thin-walled C steel channels.

\section{Finite Element Modeling}

As it is shown in Figure 10, a finite element model of composite foam concrete one-way slab is established using ABAQUS. The foam concrete is simulated using 3D C3D8R solid element, and the cold-formed thin-walled C-channel adopts 3D S4R linear quadrilateral shell element. The boundary conditions at both ends replicate the support condition during the test. Four-point loading methods were also replicated in the simulation. The mesh is shown in Figure 11.

The boundary condition and the loading procedure of the model replicate those of the test. To replicate the simply-supported condition of the slab, at one end of the slab, $\mathrm{U} 1=\mathrm{U} 2=\mathrm{U} 3=0$, and at another end, $\mathrm{U} 2=\mathrm{U} 3=0$. The plates at the support and the loading position are connected to the slab using TIE available in ABAQUS. The sensitivity analysis of the mesh was made. The grid density of 0.06 is used for the foam concrete, and 0.02 is used for the cold-formed thin-walled C steel channels. The belt and cold-formed thinwalled C steel channels are embedded into the concrete. That is, the corresponding nodes are coupled together, and it is assumed that the interfaces have no relative displacement.

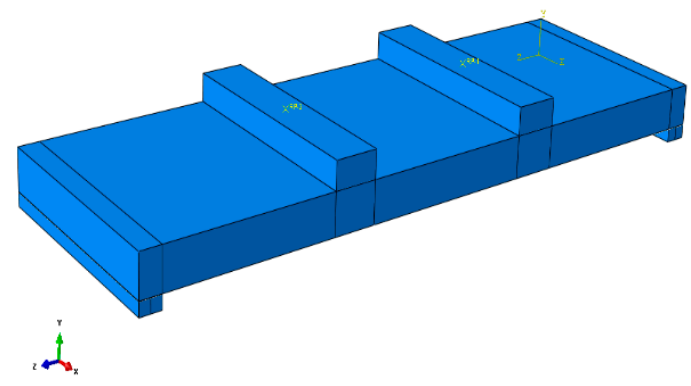

(a)

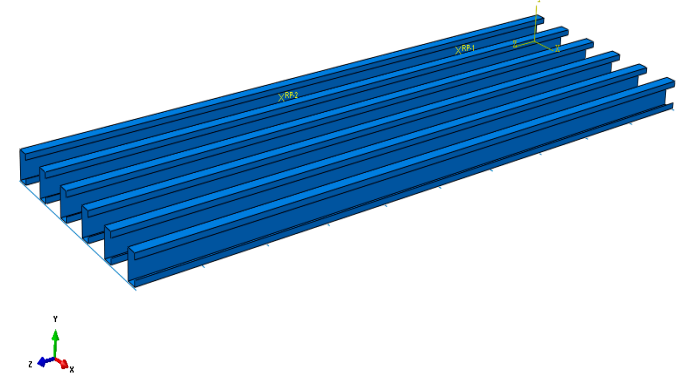

(b)

Figure 10. One-way slab model of lightweight steel and foam concrete. (a) The composite slab with loading beams and support; (b) Cold-formed thin-walled C steel channels with steel belts. 


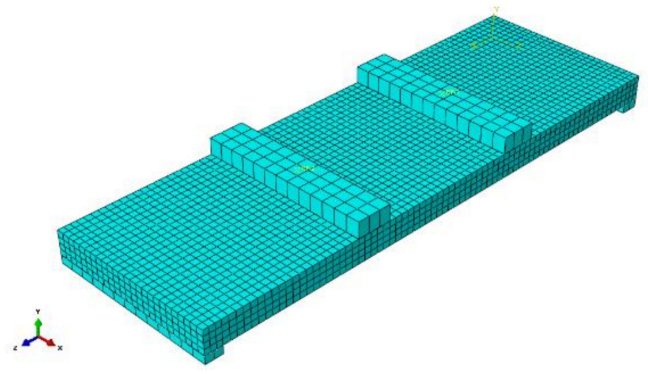

(a)

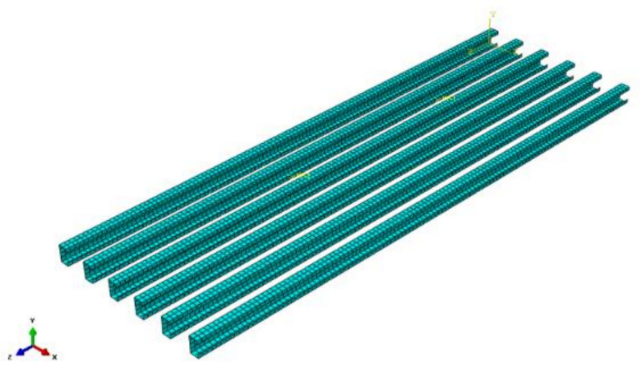

(b)

Figure 11. Mesh of the model. (a) Mesh of the foam concrete slab; (b) Mesh of cold-formed thin-walled C steel channels.

\subsection{Material Model and Dimension of the Model}

The foam concrete was simulated using the CDP model available in ABAQUS. The uniaxial stress-strain relationship obtained from the tests was input into the CDP model in ABAQUS. It was validated through the test results that the CDP model can efficiently model the cracking behaviour of the foam concrete and it is easy to converge under moth monotonic and cyclical loads. In the tension zone of the concrete, the strength of the concrete is taken as $1 / 15$, presuming that the concrete stops working after cracking. The cracking strain of the concrete is therefore taken as the total strain minus the elastic strain, which is used for the strain after the cracking of the foam concrete. The stress-strain relationship curve of the foam concrete $[14,15]$ and the steel components used in simulation are shown as follows:

1. Stress-strain relationship curve of the foam concrete:

$$
y=\left\{\begin{array}{cc}
-1.041 x^{3}+1.019 x^{2}+1.028 x-0.017 & (0 \leq x \leq 1) \\
204 x^{3}-674 x^{2}+737.1 x-266.1 & (1 \leq x \leq 1.2) \\
-0.005 x^{3}+0.052 x^{2}-0.211 x+0.559 & (x \geq 1.2)
\end{array}\right.
$$

where

$x$-is the ratio of the strain to the maximum strain;

$y$-is the ratio of the stress to the compressive strength of foam concrete.

2. Stress-strain relationship curve of the steel

A perfect elastic-plastic stress-strain relationship, using Von Mises yield criterion, is shown as follows:

$$
\sigma=\left\{\begin{array}{cc}
E_{s} \varepsilon & \left(-\varepsilon_{y} \leq \varepsilon \leq \varepsilon_{y}\right) \\
f_{y} & \left(\varepsilon>\varepsilon_{y}\right) \\
-f_{y} & \left(\varepsilon<-\varepsilon_{y}\right)
\end{array}\right.
$$

where

$\sigma$-stress of the steel;

$\varepsilon$-strain of the steel;

$E_{s}$-Young's modulus;

$f_{y}$-yield stress;

$\varepsilon_{y}$-yield strain is the limit value of strain.

Taking slab1 as an example, the size of the composite panels is $3000 \times 1000 \times 150 \mathrm{~mm}$, the size of the cold-formed thin-walled C steel channel is $100 \times 50 \times 20 \mathrm{~mm}$, with wall thickness is $2 \mathrm{~mm}$, and the spacing of cold-formed thin-walled C steel channels is 180 $\mathrm{mm}$. The density of the foam concrete is $1200 \mathrm{~kg} / \mathrm{m}^{3}$ and the steel is Q235B. The concrete parameters of foam concrete are shown in Table 2. 
Table 2. Simulation of the foam concrete and cold-formed thin-walled C-channel.

\begin{tabular}{cccccc}
\hline Material & $\begin{array}{c}\text { Density } \\
\left(\mathbf{k g} / \mathbf{m}^{\mathbf{3}}\right)\end{array}$ & $\begin{array}{c}\text { Compressive } \\
\text { Strength/MPa }\end{array}$ & $\begin{array}{c}\text { Tensile } \\
\text { Strength/MPa }\end{array}$ & $\begin{array}{c}\text { Young's } \\
\text { Modulus/MPa }\end{array}$ & Poisson's Ratio \\
\hline C-channel & 7800 & 300 & 300 & $2.05 \times 10^{5}$ & 0.30 \\
Foam concrete & 1200 & 17.8 & 2.4 & $2.73 \times 10^{3}$ & 0.20 \\
\hline
\end{tabular}

\subsection{Model Validation}

The model is validated using the test results. Figure 12 shows the stress distribution of the foam concrete and cold-formed thin-walled C steel channels. It shows the Mises stress contour of both foam concrete and cold-formed thin-walled $C$ steel channels; the unit is Pa. It can be seen that, when composite slabs are loaded to the ultimate state, due to the cracking, the slab is divided into several segments, and therefore show three red line regions in Figure 12.

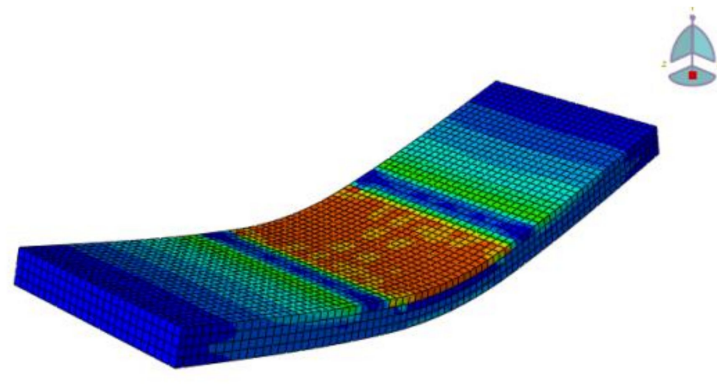

(a)

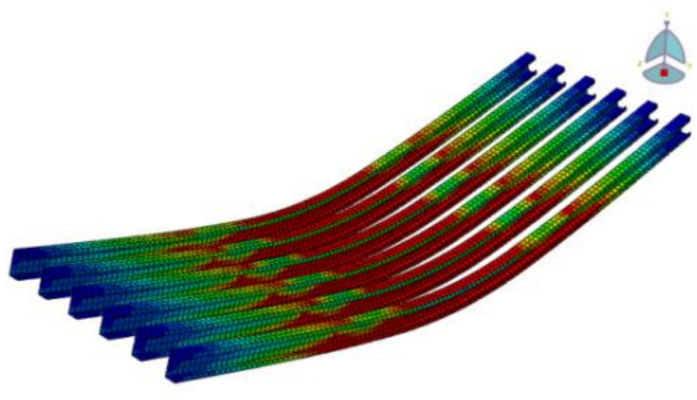

(b)

Figure 12. Stress contour of composite slab under ultimate load. (a) Foam concrete slab; (b) Cold-formed thin-walled C steel channels.

Figure $13 \mathrm{~b}$ shows the crack patterns for the middle $1200 \mathrm{~mm}$ of the span, and the unit is Pa. From the comparison of Figures 13 and 14, it can be seen that the numerical model can catch most of the cracks from the real tests; the crack patterns are similar to the test results. However, it failed to simulate these small hair cracks.

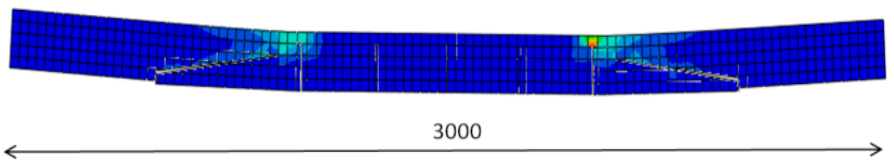

(a)

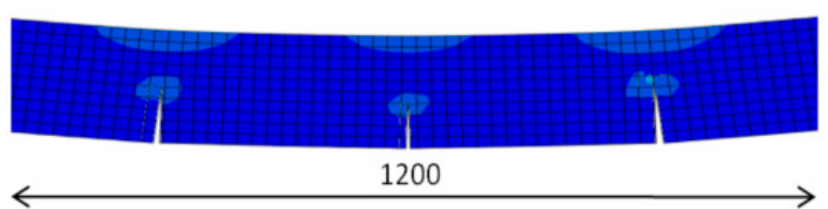

(b)

Figure 13. Crack distributions of composite slabs in numerical model (mm). (a) Cracks developed in the whole length of composite slabs; (b) Cracks in the middle of composite slabs. 

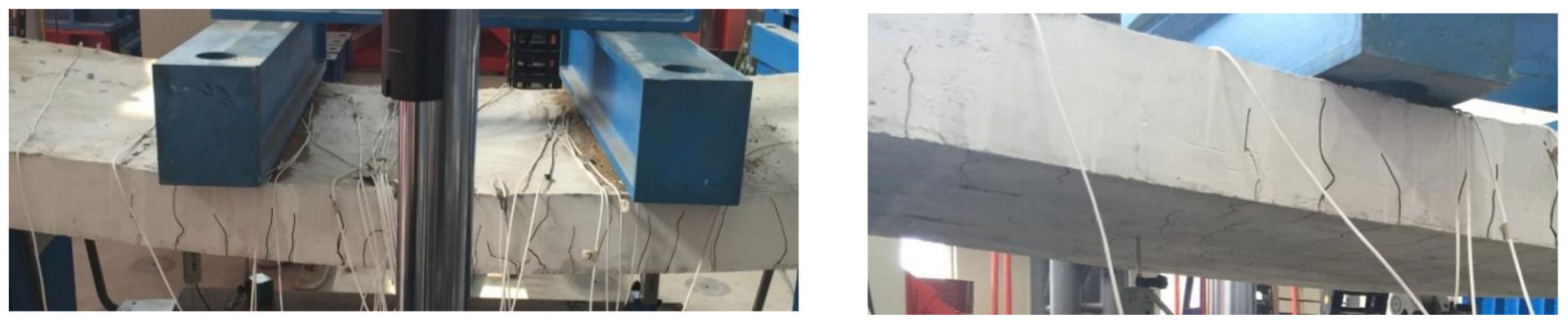

Figure 14. Crack distributions of composite slabs in tests.

The modeling results were validated against the test results as shown in Figures 15-18 and Table 3. The experimental results are in good agreement with the simulation results. Figure 15 is a load-deflection comparison curve.

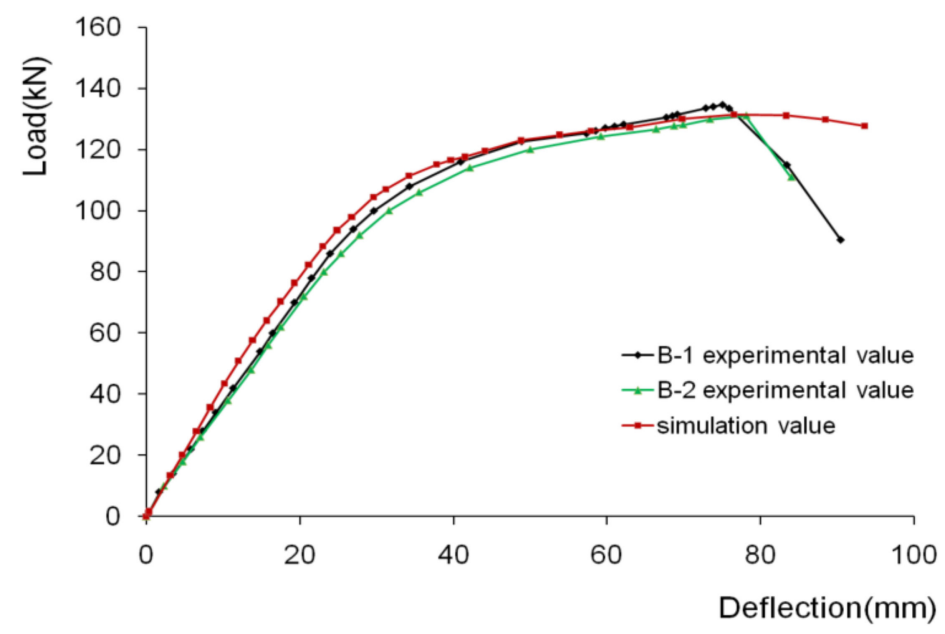

Figure 15. Comparison of experimental and simulated load deflection curves.

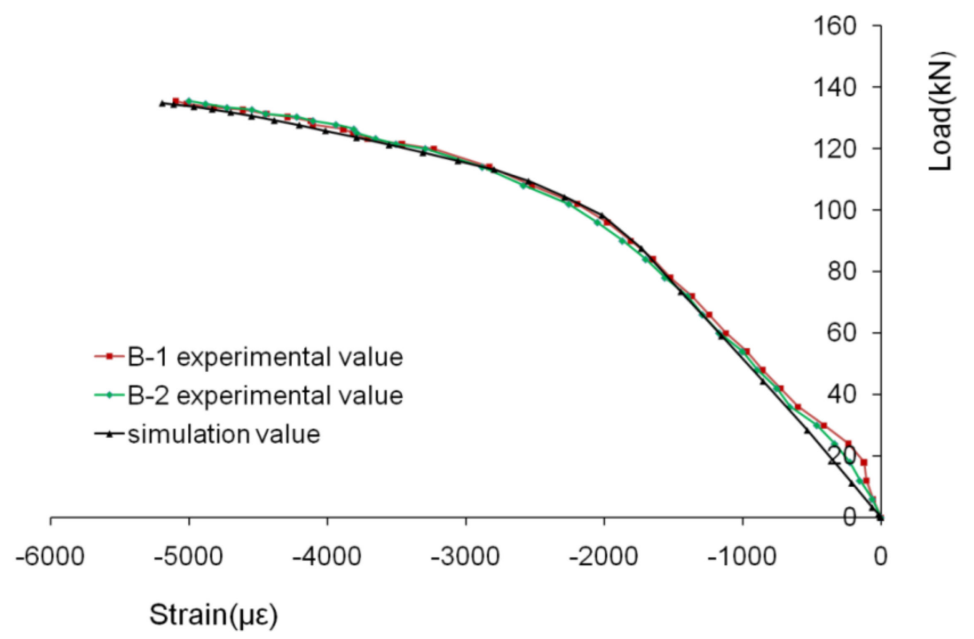

Figure 16. Comparison of load-strain curves of foam concrete. 


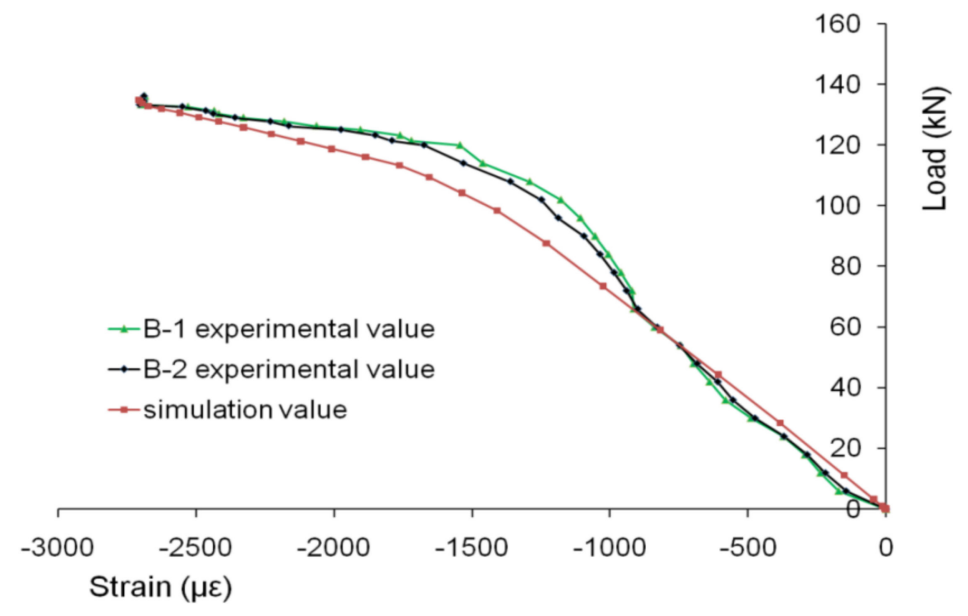

Figure 17. Comparison of load-strain curves of steel upper flange.

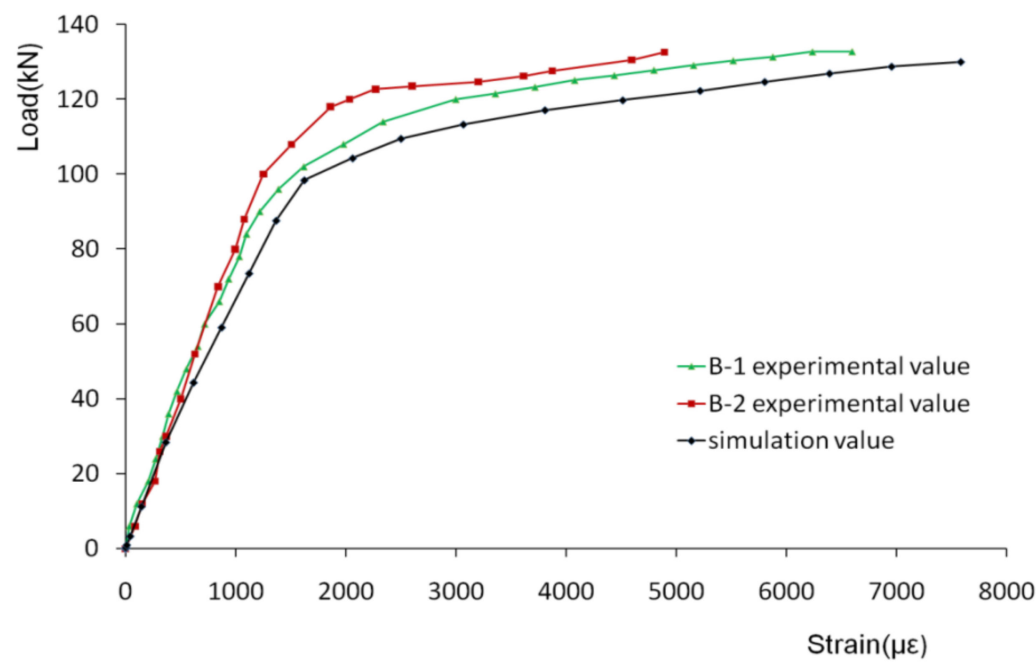

Figure 18. Comparison of load-strain curves of steel lower flange.

Table 3. Comparison of simulation and test data.

\begin{tabular}{cccc}
\hline Testing Stages & $\begin{array}{c}\text { Mid-Span Deflection from } \\
\text { FE Model (mm) }\end{array}$ & $\begin{array}{c}\text { Mid-Span Deflection from } \\
\text { Test (mm) }\end{array}$ & Simulation Value/Test Value \\
\hline Stage 1 & 5.51 & 5.99 & 0.92 \\
Stage 2 & 25.65 & 25.55 & 1.003 \\
Stage 3 & 85.806 & 82 & 1.046 \\
\hline
\end{tabular}

Note: Stage 1 is the cracking stage. When a crack starts to form in the concrete, the cracking load of the foam concrete is taken as the load when the cracking in the FE model is first noticed. Stage 2 is the plastic stage, when the bottom flange of the cold-formed thin-walled $\mathrm{C}$ steel channels yield. Stage 3 is the failure state, when cold-formed thin-walled C steel channels yield as well as the crushing of the concrete occurs.

Figure 16 is a comparison of load-strain curves of foam concrete; the strain is taken as the compressive strain in the top surface of the foam concrete at the midspan section of the slab.

Figures 17 and 18 are the comparisons of strain on the upper and bottom flange of cold-formed thin-walled $C$ steel channels. Figure 17 shows the compressive strain in the top flange of cold-formed thin-walled $C$ steel channels in the midspan, and Figure 18 shows the tensile strain in the bottom flange of the cold-formed thin-walled $\mathrm{C}$ steel channels in the midspan. 


\section{Parametric Studies Using FE Model}

Parametric studies were performed using ABAQUS finite element model, showing the effects of different parameters on the bearing capacity and failure mechanism of composite slabs. Cold-formed thin-walled $C$ steel channels were symmetrically arranged with steel belts. The width and thickness of steel strips are $50 \mathrm{~mm}$ and $2 \mathrm{~mm}$. The length of steel strips is the same as the width of cold-formed thin-walled C steel channels.

\subsection{Effect of the Space of the Cold-Formed Thin-Walled CSteelChannels}

The mechanical properties of models J-1to J-4 are shown in Table 4. Figure 19 shows the load-deflection curves of cold-formed thin-walled $C$ steel channels under four different spacing. In the elastic stage, with the decrease of the spacing between cold-formed thinwalled $C$ steel channels, the steel content of the corresponding composite plate increases and the slope of the curve increases, indicating that the stiffness of the composite plate is improved. At the same time, the bearing capacity and ultimate load of the corresponding model in the plastic stage are also improved. According to the analysis of the influence of simulated cold-formed thin-walled C steel channels' spacing on the ultimate bearing capacity of the composite plate, the ultimate bearing capacity of the lightweight steel foam concrete composite one-way slab will be increased by $0.23-0.76 \%$ when the steel component increases by $1 \%$. In conclusion, the change of spacing of cold-formed thin-walled $C$ steel channels not only affects the stiffness of composite slabs, but also acts as an important factor affecting the bearing capacity of composite slabs.

Table 4. Mechanical properties of models J-1 to J-4.

\begin{tabular}{|c|c|c|c|c|}
\hline Model Number & Ratio of C-Channels \% & $\begin{array}{l}\text { Tensile Strength of } \\
\text { Steel MPa }\end{array}$ & $\begin{array}{l}\text { Density of Foam } \\
\text { Concrete } \mathrm{kg} / \mathrm{m}^{3}\end{array}$ & $\begin{array}{l}\text { Compressive Strength of } \\
\text { Foam Concrete MPa }\end{array}$ \\
\hline $\mathrm{J}-1$ & 1.92 & 235 & 1200 & 17.0 \\
\hline $\mathrm{J}-2$ & 1.60 & 235 & 1200 & 17.0 \\
\hline $\mathrm{J}-3$ & 1.28 & 235 & 1200 & 17.0 \\
\hline $\mathrm{J}-4$ & 0.96 & 235 & 1200 & 17.0 \\
\hline
\end{tabular}

N.B. The ratio of C-channels is the ratio of the total area of the cold-formed thin-walled C steel channels cross-section/total area of the concrete cross-section.

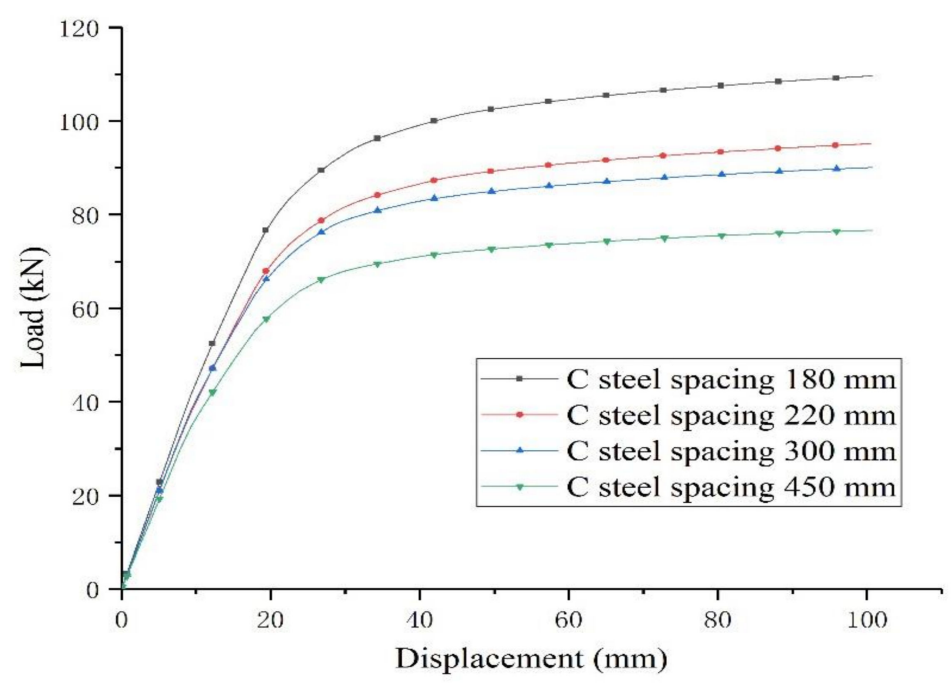

Figure 19. Load displacement curves of composite slabs with different cold-formed thin-walled C steel channels spacing.

\subsection{Effect of the Grade of the Cold-Formed Thin-Walled C Steel Channels}

The influence of strength of four kinds of steel on composite plate was analyzed. Selected model parameters are: transverse belt spacing are $200 \mathrm{~mm}$, foam concrete density 
is $1200 \mathrm{~kg} / \mathrm{m}^{3}$ (see Table 5), and the grade of the cold-formed thin-walled C steel channels are $235,345,390$, and $420 \mathrm{MPa}$, respectively.

Table 5. Mechanical properties for foam concrete.

\begin{tabular}{ccccc}
\hline Density kg/m & Young's Modulus MPa & Poisson's Ratio & Compressive Strength MPa & Tensile Strength MPa \\
\hline 800 & $1.75 \times 10^{3}$ & 0.2 & 7.8 & 0.52 \\
1000 & $2.29 \times 10^{3}$ & 0.2 & 10.2 & 0.68 \\
1200 & $2.73 \times 10^{3}$ & 0.2 & 17.0 & 1.13 \\
1600 & $3.29 \times 10^{3}$ & 0.2 & 21.5 & 1.43 \\
\hline
\end{tabular}

Figure 20 shows load-deflection comparison curves. The load-carrying capacity and ultimate load of the corresponding model in the plastic stage are improved due to the increase of the strength of steel. In the elastic change stage, the slopes of different models are the same. Therefore, increasing the strength of steel does not have a greater impact on the overall stiffness of the composite plate. According to the analysis of the influence of the steel strength on the ultimate bearing capacity of the composite slabs, the ultimate bearing capacity of the lightweight steel foam concrete composite one-way slab will be increased by $0.65-0.72 \%$ when the strength is increased by $1 \%$.

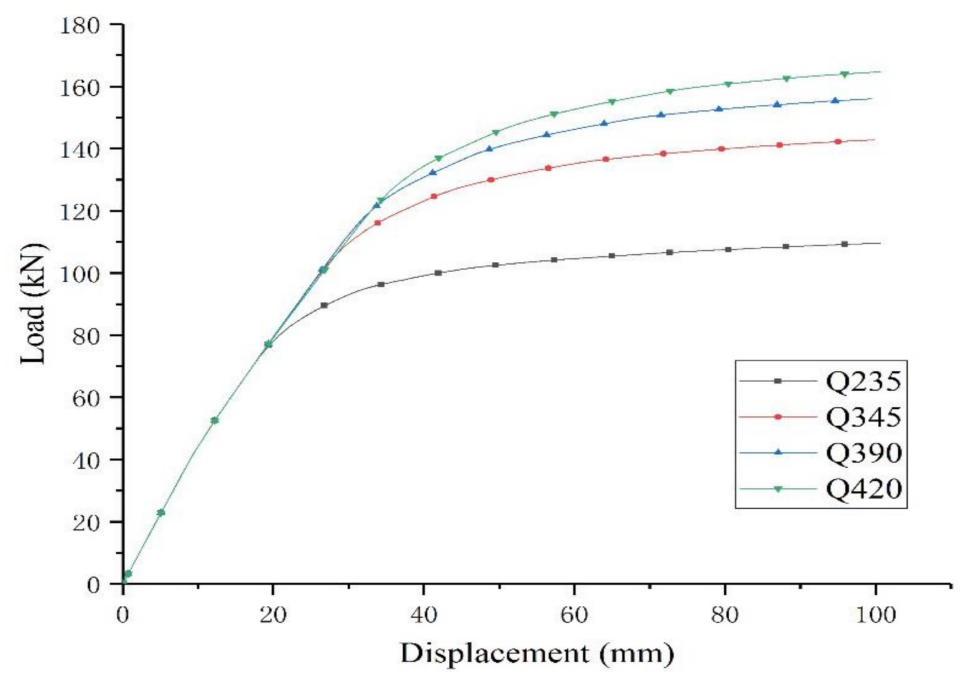

Figure 20. Load displacement curves of different steel strength.

\subsection{Effect of the Compressive Strength of the Foam Concrete}

The densities of the foam concrete used are: $800,1000,1200$, and $1600 \mathrm{~kg} / \mathrm{m}^{3}$; the compressive strength of the foam concrete is shown in Table 5. The model labels are, respectively, P-1, P-2, P-3, and P-4. First, the model is built without considering the influence of other variables on the foamed concrete. The thickness of cold-formed thinwalled C steel channels is set to $2 \mathrm{~mm}$, the strength of steel is $235 \mathrm{MPa}$, the spacing between cold-formed thin-walled C steel channels is $180 \mathrm{~mm}$, and the spacing between transverse strips is $200 \mathrm{~mm}$; that is, only one factor of foam concrete density is considered.

Figure 21 shows load-deflection comparison curves. With the increase of the compressive strength of the foam concrete, the ultimate bearing capacity of composite panels also increases. According to [33], the larger the density of the foam concrete, the higher the compressive strength, therefore the higher flexural capacity of the composite slabs. In the elastic stage, the foam concrete modulus decreases with the decrease of the foam concrete grade. As the compressive strength of the foam concrete increases, the stiffness of the whole model increases; if the stiffness of the whole model increases, the smaller the deformation. According to the corresponding compressive strength values of foam concrete 
with different density grades, the ultimate bearing capacity of a lightweight steel foam concrete composite one-way slab will be increased by $0.17-0.23 \%$ per $1 \%$ increase. To sum up, for the simulated lightweight steel foam concrete composite one-way slab, increasing the compressive strength of foam concrete will increase the stiffness of the composite slab and contribute to the improvement of the composite plate bearing capacity.

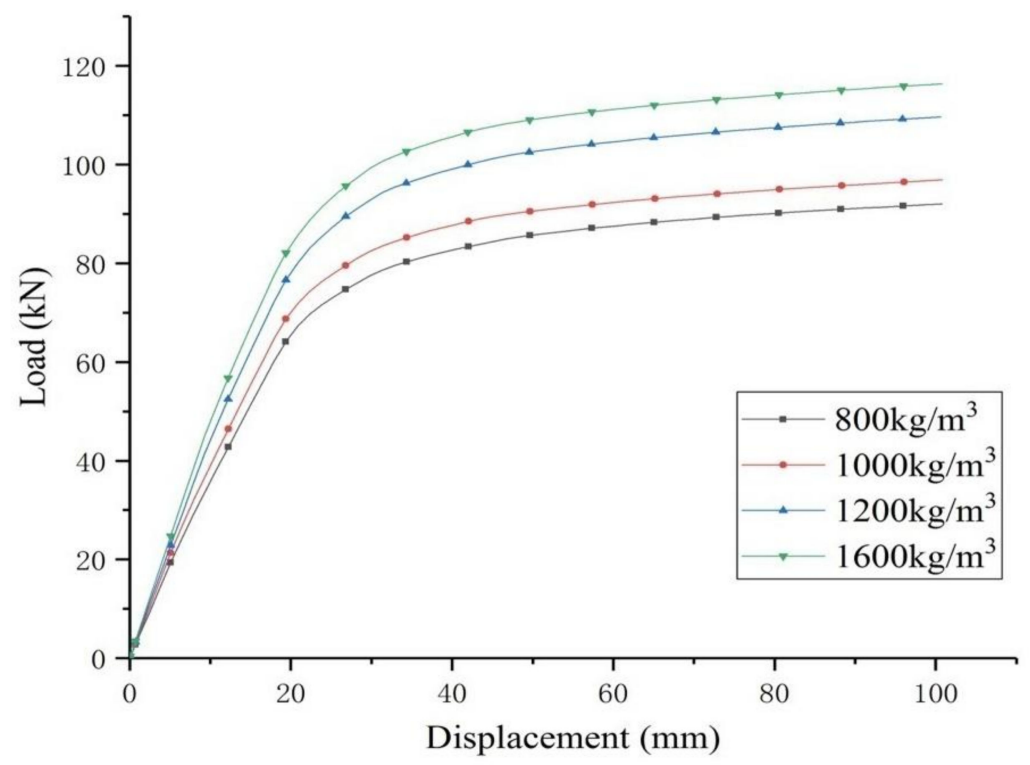

Figure 21. Load displacement curves of different grades of foam concrete.

\section{Conclusions}

In this paper, a new composite floor system using cold-formed thin-walled C steelchannels embedment and foam concrete slab is developed. This new type of floor system features lightweight, high fire-resistant, and high anti-corrosion features, and can be used for multi-story buildings, providing a promising new alternative floor system for the construction market.

The full-scale tests as well as FE modelling were performed to study the flexural capacity and failure mechanism of composite foam concrete slabs using cold-formed thin-walled $C$ steel channels.

Using the FE model, main factors, such as the density of the foam concrete, the strength of the steel, and the spacing of the cold-formed thin-walled C steel channels are studied. The below findings are made:

1. The test shows that the composite floor formed by foamed concrete and cold-formed thin-walled C steel channels shows good bearing capacity and deformation capacity, but the stiffness of the composite floor is relatively small. When reaching the limit state, the upper and lower flanges and part of the webs of the cold-formed thin-walled $\mathrm{C}$ steel channels have reached the yield strength, and the plastic deformation of the composite floor has been fully developed.

2. The comparison of the load-deflection curve and load-strain curve shows that the simulation results are in good agreement with the test results.

3. The smaller the spacing of cold-formed thin-walled $C$ steel channels, that is, the greater the steel content, the higher the load-bearing capacity of the composite floor.

4. The higher the compressive strength of the foamed concrete, the higher the bearing capacity of the composite floor slab, while the stiffness increases.

5. The increase of the steel strength of the cold-formed thin-walled $C$ steel channels can increase the bearing capacity of the composite floor, but it has almost no effect on the stiffness of the composite floor. 
The limitation of the project research is that, as a new material, high-density foam concrete is used. The rigidity of this new composite floor slab is relatively small, and cracks often appear prematurely. Researches on mechanical properties of this type of floor is still little and not mature enough, and the modelling analysis in this article does not consider the bond slip between the cold-formed thin-walled $\mathrm{C}$ steel channels and foam concrete. In future studies, in-depth and detailed research will be carried out in response to the limitations of this research. In the meantime, research on two-way composite slabs and composite shear walls and the connection between the slabs and walls will also be conducted.

Author Contributions: Original draft preparation: D.L. and F.F.; conception: D.L. and F.F.; test and data processing: W.L.; writing-review and editing: F.F.; project administration: D.L. All authors have read and agreed to the published version of the manuscript.

Funding: This research was funded by the National Natural Science Foundation of China, grant number 51378238 .

Institutional Review Board Statement: Not applicable.

Informed Consent Statement: Not applicable.

Data Availability Statement: The data used to support the findings of this study are available from the authors upon request.

Conflicts of Interest: The authors declare no conflict of interest.

\section{References}

1. Liu, D.; Wang, F.; Fu, F.; Wang, H. Experimental research on the failure mechanism of foam concrete with C-channel embedment. Comput. Concr. 2017, 20, 263-273.

2. Liu, D.; Wang, F.; Fu, F. Experimental Research on the Shear Connectors in Foam Concrete with C-channel Embedment. Int. J. Concr. Struct. Mater. 2018, 12, 51. [CrossRef]

3. Mydin, M.A.O.; Wang, Y.C. Elevated-temperature thermal properties of lightweight foamed concrete. J. Constr. Build. Mater. 2011, 25, 705-716.

4. Ibrahim, W.; Jamaluddin, N.; Irwan, J.M.; Ramadhansyah, P.J.; SurayaHani, A. Compressive and flexural strength of foamed concrete containing polyolefin fibers. Adv. Mater. Res. 2014, 911, 489-493. [CrossRef]

5. Yan, J.B.; Guan, H.N.; Wang, T. Numerical studies on steel-UHPC-steel sandwich beams with novel enhanced C-channels. J. Constr. Steel Res. 2020, 170, 106070. [CrossRef]

6. Sohel, K.M.A.; Richard, L.J.Y.; Yan, J.B.; Zhang, M.H.; Chia, K.S. Behavior of Steel-Concrete-Steel sandwich structures with lightweight cement composite and novels hear connectors. Compos. Struct. 2012, 94, 3500-3509. [CrossRef]

7. Yue, L.; Bing, C. New type of super-lightweight magnesium phosphate cement foamed concrete. J. Mater. Civ. Eng. 2015, 27, 04014112. [CrossRef]

8. Ikponmwosa, E.; Falade, F.; Fapohunda, C.; Akinniyi, T.; Olori, K. Effect of foam concentration on structural characteristics of steel reinforced aerated concrete beams. Pac. J. Sci. Technol. 2014, 15, 32-46.

9. KunhanandanNambiar, E.K.; Ramamurthy, K. Models relating mixture composition to the density and strength of foam concrete using response surface methodology. Cem. Concr. Compos. 2006, 7, 752-760.

10. Jones, M.R.; Carthy, A.M. Heat of hydration in foamed concrete: Effect of mix Constituents and Plastic density. Cem. Concr. Res. 2006, 36, 1032-1041. [CrossRef]

11. Kearsleya, E.P.; Wainwright, P.J. The effect of high flyash content on the compressive strength of foamed concrete. Cem. Concr. Res. 2001, 31, 105-112. [CrossRef]

12. Hashimoto, A.; Hayashi, S.; Yamamoto, S.; Chujo, H. Process of Continuous Manufacture of Light-Weight Foamed Concrete. US Patent US4057608, 8 November 1977.

13. American Ironand Steel Institue. AISI S100-16, North American Specification for the Design of Cold-Formed Steel Structural Members; draftedition; CSA GROUP: Toronto, ON, Canada, 2001.

14. GB50018-2002. Technical Code of Cold-Formed Thin-Wall Steel Structures. Chinese Standard; China Planning Press: Beijing, China, 2002.

15. Wright, H.D.; Evans, H.R. A folded plate method of analys is for profiled steel sheeting in composite floor construction. Thin-Walled Struct. 1987, 5, 21-37. [CrossRef]

16. Helmut, B.; Ingeborg, S. Zur Berechnungdurchlaufender Verbunddecken. Calculation of continuous composite slabs. Stahlbau 1997, 66, 416-426.

17. Elghazoul, A.Y.; Izzuddin, B.A. Realistic Modeling of Composite and Reinforced Comcrete Floor Slabsunder Extreme Loding. J. Struct. Eng. 2004, 130, 1985-1996. [CrossRef] 
18. Crisinel, M.; Marimon, F. A new simplified method for the design of composites labs. J. Constr. Steel Res. 2004, 60, 481-491. [CrossRef]

19. Jeong, Y.-J. Simplified model to predict partial-interactive structura lperformance of steel-concrete composites labs. J. Constr. Steel Res. 2008, 64, 238-246. [CrossRef]

20. Fu, F. Design and Analysis of Tall and Complex Structures; Elsevier: Oxford, UK, 2018; pp. 1-304.

21. Fu, F. Advanced Modelling Techniques in Structural Design; JohnWiley \& Sons: Oxford, UK, 2015; ISBN 978-1-118-82543-3.

22. Fu, F. Structural Analys is and Design to Prevent Disproportionate Collapse; CRCPress: Boca Raton, FL, USA, 2016; ISBN 978-1-49878820-5.

23. Deng, X.-F.; Liang, S.-L.; Fu, F.; Qian, K. Effects of High-Strength Concrete on Progressive Collapse Resistance of Reinforced Concrete Frame. J. Struct. Eng. 2020, 146, 04020078. [CrossRef]

24. Guo, L.; Liu, Y.; Fu, F.; Huang, H. Behavior of axially loaded circular stain less steel tube confined concrete stubcolumns. Thin-Walled Struct. 2019, 139, 66-76. [CrossRef]

25. Qian, K.; Liang, S.-L.; Fu, F.; Fang, Q. Progressive collapse resistance of precast concrete beam-column sub-assemblages with high-performance dry connections. Eng. Struct. 2019, 198, 109552. [CrossRef]

26. Wang, L.; Shen, N.; Zhang, M.; Fu, F.; Qian, K. Bond performance of Steel-CFRP barre in forced coral concrete beams. Constr. Build. Mater. 2020, 245, 118456. [CrossRef]

27. Fu, F.; Lam, D.; Ye, J. Moment resistance and rotation capacity of semi-rigid composite connections with precast hollow core slabs. J. Constr. Steel Res. 2010, 66, 452-461. [CrossRef]

28. Fu, F. Fire induced progressive collapse potential assessment of steel framed buildings using machine learning. J. Constr. Steel Res. 2020, 166, 105918. [CrossRef]

29. Fu, F.; Parke, G.A.R. Assessment of the Progressive Collapse Resistance of Double-Layer Grid Space Structures Using Implicit and Explicit Methods. Int. J. Steel Struct. 2018, 18, 831-842. [CrossRef]

30. GB/T700-2006. Carbon Structure Steels, Chinese Standard; Standards Press of China: Beijing, China, 2007.

31. Hong-Gun, P.; Choi, K.K.; Wight, J.K. Strain-based shear strength model for slender beams without web reinforcement. ACI Struct. J. 2006, 103, 783-793.

32. De Domenico, D.; Ricciardi, G. Shear strength of RC beams with stirrups using an improved Eurocode 2 truss model with two variable-inclination compression struts. Eng. Struct. 2019, 198, 109359. [CrossRef]

33. Liu, D.; Wang, F.; He, M. Experimental research for constitutional relationship of foam concrete under uniaxial compressions. Archit. Technol. 2016, 47, 758-760. 